\section{DIGITAL COMMONS \\ @ UNIVERSITY OF SOUTH FLORIDA}

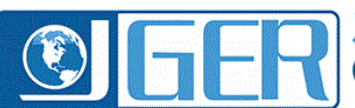

Journal of

Global Education and Research

December 2017

\title{
Hiding or out? Lesbian and gay educators reveal their experiences about their sexual identities in their K-12 schools
}

Steven D. Hooker

University of North Carolina Wilmington, hookersd@uncw.edu

Follow this and additional works at: https://digitalcommons.usf.edu/jger

\section{Part of the Education Commons}

This Refereed Article is brought to you for free and open access by the M3 Center at the University of South Florida Sarasota-Manatee at Digital Commons @ University of South Florida. It has been accepted for inclusion in Journal of Global Education and Research by an authorized editor of Digital Commons @ University of South Florida. For more information, please contact digitalcommons@usf.edu.

\section{Recommended Citation}

Hooker, S. D. (2017). Hiding or out? Lesbian and gay educators reveal their experiences about their sexual identities in their K-12 schools. Journal of Global Education and Research, 1(1), 35-47.

https://www.doi.org/10.5038/2577-509X.1.1.1007

Revisions

Submission date: 06.22 .2017

1st Revision: 10.16 .2017

Acceptance: 10.30.2017 


\title{
Hiding or Out? Lesbian and Gay Educators Reveal Their Experiences About Their Sexual Identities in Their K-12 Schools
}

\author{
Steven D. Hooker \\ Watson College of Education \\ University of North Carolina Wilmington, USA \\ hookersd@uncw.edu
}

\begin{abstract}
This qualitative study explored the ways in which lesbian and gay educators, in the Midwest part of the country, negotiate their sexual identities in their school settings. Ten gay and lesbian public and Catholic school educators from rural, suburban, and urban schools were interviewed. The purpose of this study was to determine how gay and lesbian teachers negotiate their identities and how those negotiated identities affect their relationships in their school communities. Four gay and lesbian teachers and two gay administrators from public schools were interviewed about their experiences in their school settings. Additionally, a focus group of five Catholic school educators, from two different schools, was conducted. Each of these educators negotiated their sexual identities differently within their school communities; however, descriptors such as age, experience level, and school setting did not affect their identity negotiation. Most of these educators were unable to negotiate their sexual identity with their teacher identity due to fear of intimidation and discrimination, or being fired. The only exceptions being when they cautiously negotiated their sexual identities with a few of their colleagues. This raises questions about school policy and school culture for the inclusion of gay and lesbian individuals in schools.
\end{abstract}

Keywords: gay and lesbian educators, school policy, inclusive school culture, relationships within school communities

\section{Introduction}

Over the past 10 years, lesbian, gay, bisexual and transgender (LGBT) issues have been openly discussed during election campaigns; the Don't Ask, Don't Tell policy for gay men, lesbians and bisexuals has been eliminated, same-sex marriages have been legalized, and many television programs now feature at least one gay man or lesbian character. Additionally, the federal government, as well as many public and private companies, have policies that prevent discriminating against LGBT individuals. Nevertheless, discrimination against homosexuals may be the last form of bigotry that is considered acceptable. "Current federal, state, and local laws, and voluntary corporate policies, are insufficient to address the pervasive discrimination against gay and lesbian individuals" (Pizer, Sears, Mallory, \& Hunter, 2012, p. 715). While discrimination against other marginalized groups in school settings is now illegal, discrimination against sexual minorities is a common practice (Bishop, Caraway, \& Stader, 2010). 


\section{Homophobia in Public Schools}

Despite the vast changes to our social landscape over the past few decades, the K-12 educational institutions still remain patriarchal, heteronormative systems (Lugg, 2003). There are exceptions for many differences including gender, race, ethnicity, and religion in school policy, yet the lesbians and gay men are not part of that protected class. Wright (2010) argues that despite progress, "schools continue to struggle with how to improve experiences for LGBT students. Yet school leaders struggle even more with acknowledging and improving the experiences of LGBT educators" (p. 50). Sexual orientation discrimination is still permitted in many school districts across the United States. As some researchers have noted, "teachers who are of the sexual minority (gay, lesbian, or bisexual) must remain closeted or risk losing their jobs" (Bishop, et al., 2010, p. 84).

\section{Homophobia in Parochial Schools}

While public school educators are submerged into an institutionalized heteronormative setting, Catholic school gay and lesbian teachers experience deepened levels of discrimination from the religious ideology in their homophobic school settings. Most lesbian, gay, and bisexual teachers chose to work at Catholic schools because of their religious beliefs, but they also saw conflicts between their religion and their lifestyles (Maher \& Server, 2007). These teachers experienced oppression and feared coming out to students, despite the belief that it might benefit their teaching. They also held the belief that they would not be supported by their administrators (Maher, 2003). Unfortunately, many religions not only decry the gay lifestyle, but have specific policies and practices which condemn homosexuality (Maher \& Server, 2007).

\section{Literature Review}

The literature review has been divided into two sections: identity negotiation and relationship formation and maintenance. There is a body of research supporting gay and lesbian educators struggling with identity negotiation and another supporting gay and lesbian educators with their school relationships. I could not, however, identify any research that looked at both identity negotiation and relationships with the same group of educators.

\section{Identity Negotiation}

Teaching is negativity associated both with "public debates about the recognitions of LGB lifestyles with school curriculums and the perceived reactions of parents and other to their children having a lesbian, gay, or bisexual teacher" (EHRC, 2009, p. 20). In their report, the Equity and Human Rights Commission found that only $51 \%$ of lesbians, $52 \%$ of gay men felt comfortable about being open about their sexual orientation, without fear of discrimination, in their educational environments (EHRC, 2009).

Jackson (2006) conducted a study to identify the contextual factors that promote or prohibit the construction of identities as gay teachers. She interviewed nine K-12 gay and lesbian teachers four times each and conducted a focus group. She found that contextual factors contribute to and inhibit the amalgamation of gay and lesbian identities with teacher identities, and what she refers to as "gay teacher identity development process" (Jackson, 2006, p. 27). Many factors interacted with each other to influence classroom practice. "Coming out served to bring two major aspects of participants' identities together, being gay and being a teacher, aspects they previously viewed as 
irreconcilable" (Jackson, 2006, p. 31). All of these factors interact to help or hinder growth as gay or lesbian teachers (Jackson, 2006).

Unless males, regardless of the heterosexuality or homosexuality status, "can pass as masculinist leaders, the gendered expression, they may have difficulty in being hired" (Lugg, 2003, p. 118). In 2009, DeLeon and Brunner studied the experiences of LGBT school administrators. They found that "when participants had early fears of being outside the accepted norm and fear for their personal safety on a daily basis, several LGBT administrators spoke of turning to assimilation and silence" (p. 164). They learned to negotiate their identities through silence in the environment of heteronormativity and privilege (DeLeon \& Brunner, 2009). Many male teachers express the need to pass as heterosexual to feel safe in their school environments.

In 2001, Maher found that words like denial and repression were used when interviewing gay and lesbian students and staff in Catholic high schools (p. 108). Alberts, a gay male counselor in a Catholic high school, agreed with the use of words like denial and repression to describe his experience (Maher, 2001). According to Alberts, "It's like taking a part of your being and closing it off in scar tissue and setting it aside. You feel like there's a hole in your feelings, thoughts, and being, your spirituality is never addressed" (Maher, 2001, p. 108). Nearly all of the educators Maher (2001) interviewed agreed that homosexuality was rarely or never presented in the curricula at their schools, making gay men and lesbians invisible in society.

"Father Coleman would demand that a teacher in a Catholic school keep secret the fact that he or she is homosexual" (Gumbleton, 2001, p. 19). These educators are encouraged to accept and love themselves for who they are, and be confident that God loves them (Gumbleton, 2001). However, forbidding gay and lesbian educators from teaching authentically, unreservedly insinuates that there is something wrong with them (Gumbleton, 2001). Gay, lesbian, and bisexual educators often feel that there is something wrong with them, as they are unable to be their authentic selves in their schools.

\section{Relationship Formation and Maintenance}

In 2008 Mayo analyzed two sets of complex relationships in school. One relationship was between gay teachers and their students, while the other was the relationship between those same gay teachers and their colleagues. He found that the "gay teachers in this study addressed gay students' needs and demonstrated support in a variety of ways, despite working in school settings that often held a hostile perception of the GLBT community" (Mayo, 2008, p. 1).

Davis (2005) a seventh and eighth grade language arts and social studies teacher in California stated that he was prepared to respond to questions about his sexual orientation. He had not thought about how he would respond when one of his students asked about his marriage status. He thought about what he had been told to say as a standard response: "That's a personal question and personal questions are inappropriate" (p. 25), fearing what repercussions might occur.

In Mayo's (2008) study of seven gay men who taught in public and private schools, their ages ranged from 26 to 54 years and they taught in grades 6-12. Only one participant was openly gay to colleagues and students at school. Others had chosen to come out to only some of their colleagues. "Overall, the informants perceive guarded, cordial relationships with their colleagues, 
where professionalism and teamwork, combined with privacy and discretion, have become the norm at school" (Mayo, 2008, p. 7).

\section{Methods}

This IRB-approved qualitative study involved interviewing six public school and five Catholic school educators, who were gay men and lesbians, from a Midwestern area of the United States, considered part of the Bible belt, in 2010. The participant's ages ranged from 27-62 years and their years of experience ranged from 4-37 years in education.

The focus of this research was to explore the experiences of public and Catholic school teachers and administrators who identify themselves as gay men or lesbian. This section provides a description of the methodology for this qualitative research using interviews and a focus group. The findings from this qualitative research reveal an insight and understanding about how gay and lesbian teachers and administrators negotiate their identities in their school environments, and how it affects their relationships in their school communities.

The first stage of the research, the six individual interviews, was completed over a four-week period. I recorded the individual interviews, as well as the focus group and transcribed the tape recordings. Each participant was then sent the transcription to review and approve prior to it being analyzed for my research. None of the subjects requested that their transcript be changed, even when it included thoughts of lust and desire or condemning their administrators or colleagues.

Six individual educators, four teachers and two administrators in public schools, were interviewed. Once those interviews were complete, and the themes and specific categories had been identified, they were used to develop the focus group discussion prompts. The comments from those discussions were compared to the individual interview responses in an attempt to identify patterns and themes among all gay and lesbian educators. All participants were asked to tell their stories about their relationships and experiences as either an open or closeted gay or lesbian K-12 educator. A narrative analysis includes in-depth interview transcripts, life history narratives, historical memoirs, and creative nonfiction (Patton, 2002). "Narrative studies are also influenced by phenomenology's emphasis on understanding lived experiences and perceptions of those experiences" (Patton, 2002, p. 115).

\section{Participant Selection}

The participants for this study were contacted through private social functions, homosexual rights marches, personal acquaintances, and civic organization contacts. Participants were personal acquaintances who were contacted asking them to participate in a research project investigating ways they negotiate their sexual identities in their school settings, and how it affected the relationships they form in their schools. Specifically identified were individuals from elementary and high schools, as well as rural, suburban, and urban schools. Also considered were those who were practicing teachers, administrators, and coaches in an attempt to have a variety of perspectives represented in the study. Another characterizing feature recognized was the years of experience and age, as well as the number of Catholic and public-school educators. The final determining factor was the gender of the educators, as both men and women needed to be represented in the study to determine if the experiences of lesbians was different from those of gay men in the educational settings. 
Four teachers and two administrators, who self-identify as gay and lesbian educators, with whom I was socially acquainted, informally agreed to be interviewed about their experiences in their school communities. In addition to the six interviews, a focus group of five educators was conducted to gather data for this research study.

Originally, one teacher in the metropolitan Catholic school system, contacted his gay and lesbian colleagues within the school systems and asked them to participate. I had asked him to identify no fewer than four and no more than six individuals who self-identified as gay, lesbian, or bisexual teachers, who would agree to be part of the focus group discussion. If they agreed, they were given my contact information and asked to contact me directly. The Catholic school educator focus group consisted of four gay men and a lesbian.

The interviews and focus group provided the data for this research study. The participants' responses were recorded and transcribed. "Each transcription was written just as the individuals had spoken, including any slang, dialects, or pauses offered by the subject" (Berg, 2007, p. 162). The interview responses were subjected to content analysis to identify emergent patterns and themes in the responses. "Qualitative data need to be reduced and transformed in order to make them more readily accessible, understandable, and to draw out various themes and patterns" (Berg, 2007, p. 47).

\section{Findings}

This section introduces the findings from the urban, rural, and suburban, public and Catholic school educator interviews and focus group discussions used for research in this study. There were six public school educators individually interviewed and five Catholic school educators in a focus group represented in this research.

\section{Participant Interviews and Focus Group Descriptions}

As mentioned previously, individual interview participants for this study included two administrators and four teachers, and the Catholic school focus group included three teachers and two counselors. For the reporting of their stories, pseudonyms have been given to each subject, along with a few general characteristics of each subject. Pseudonyms have been also given to the educators' partners or colleagues if they were mentioned by name during the interviews or focus group discussion.

These are the six public school participants who were interviewed. Robert was 55 years-old and was a rural gay public school elementary administrator until 18 months ago, when he was fired after the superintendent learned he was a gay man. He was a teacher for five years at the elementary level, and then became an elementary school principal for $23 \frac{1}{2}$ years. Susan was a 32 -year-old lesbian high school math teacher in a rural school district. She spent all 10 years of her teaching career in the same position. Richard was a 56-year-old gay junior high and high school teacher in an area that changed from rural to suburban during his 31 years of teaching in the same school district. Adam was 44 years old and was a gay elementary school principal last year; this year he was working in a district office as the transportation director. Adam spent 11 years teaching at the elementary level, and eight years as an elementary school principal prior to becoming the district's transportation director. George who was 45 was a gay first grade teacher in an urban school environment for a large school district. He had been teaching for nine years, and had been in the 
same position all nine years of his teaching career. Teaching was a second career for George, after spending 15 years in the printing business. Edward was a 27-year-old gay special education teacher in a suburban high school. He had been teaching for four years, all in his current position. All of these educators represented six different school districts.

The Catholic high school focus group included Rose, a 61-year-old lesbian teacher; Dennis, a 51year-old gay counselor and boys' soccer coach; Scott, a 39-year-old, White gay religion teacher; David, a 62-year-old gay teacher; and Michael, a 31-year old, a gay counselor and football coach. All of the participants were Caucasian, with the exception of Michael, who was African-American. Race, however, did not affect the findings in any way.

The two themes that emerged from the individual interviews: identity negotiation, how open they can be and the challenges they face if they are out; relationships, who are the subjects open with and whether that affects their relationships. Those two themes were then used to guide the Catholic school focus group discussion.

\section{Identity Negotiation}

All participants in the research expressed varying levels of identity disclosure in their school environments citing fear as a major reason for not being out in their schools. Some were in fear of being fired, and others were in fear of being ostracized by their colleagues. All were fearful of being completely authentic in their schools, however.

Richard, a 56-year-old, gay school teacher did not have the opportunity to hide his identity. He claimed, "During the late " $80 \mathrm{~s}$, I was very active in the gay community. I even appeared on the gay television program Out Front." It was during this time that some of the students in the school saw the program and began talking about him being on the program, but were not associating it with his homosexuality. "I ran a very successful theater program. I stopped running the theatre program in '93." Richard went on to explain that it was the same year that he attended the Gay Rights March in Washington, DC, which also happened to be the year his $8^{\text {th }}$ graders took their class trip to Washington. As he was carrying the "Ohio Banner," on the outer edge of the marching group parading down the street, his $8^{\text {th }}$ graders walked down the sidewalk on their tour of the city. That Monday when he returned to school, the principal and superintendent met him at the door, claiming he had been seen at the Gay Rights March and a lot of parents were upset. "I was told that if I had been asked if I was gay, I had to lie about it, and that was probably one of the most frustrating things I've ever had to do."

Susan, a 32-year-old lesbian teacher, had been told by her administrator to hide her sexual identity as much as possible. "My colleagues know about my partner, but my students generally don't. I believe that those students who need to know, who need a role model, realize." She is, however, not able to be public about it in general. She is not able to speak about it, because there have been parents who called and wanted their children removed from her class when they found out she was a lesbian. "My administration prefers my discretion."

One distinction between Richard and Susan was the level of support from administration. While Richard received no support when parents called and complained, Susan's principal, while asking her to be discrete about her homosexuality, did support her when parents chose to make an issue 
about her being a lesbian and mother. Only two of the teachers interviewed for this study claimed to have support from their administrators regarding the issues related to their homosexuality. Most heterosexual school administrators do not believe that their sexual orientation influences their administrative practice (Capper, 1999); however, many gay and lesbian teachers disagree.

Adam, a 44-year-old administrator, however told a much different story about the negotiation of his gay identity. "I can say that I don't believe anything has been a direct result of my sexual orientation. Who's to know? I will tell you that I've always lived my life openly and never tried to hide anything." He stated that he never dated women and never claimed to have a girlfriend or allude to anything that would cause anyone to believe that he did. "Certainly, there will always be people who have their views, but I can say that people with whom I've confided about sexual orientation have been very supportive." Adam was however removed from the elementary principal position in the middle of the year, when the district superintendent learned that Adam was a gay man.

Robert, a 55-year-old administrator, had a very different experience in negotiating his sexual identity. He commented that he lived in constant fear being a gay administrator. "Living in constant fear and trying to fit in. I know there were probably some homosexual students that I could have helped, but I knew I couldn't. I knew I couldn't be who I really was or it would be professional suicide." He stated the self-hatred, self-loathing, and keeping his sexual identity quiet caused him to function in a state of constant fear. He also lost his job when his superintendent learned about his sexual orientation, due to a police report indicating that Robert had been with a male in the park committing sex acts.

The Catholic school educators negotiated their identities more cautiously than the public-school educators. When asked about how they cope with their homosexual identities within the conservative establishment of a Catholic school environment, there responses were somewhat varied. Rose struggled with her identity more than others. She commented, "I am not out, as a lesbian teacher here. I'm professional in how I deal with all of my colleagues. In the classroom, for instance kids will call me Mrs. (Smith), and I don't stop them or correct them."

Michael, an African-American Catholic school counselor and football coach, described how he felt being a gay educator. "There's just so much more restriction. I see that it's a bigger issue than the color issue. It affects me on a daily basis." He claims that while everyone else has a sense of freedom, he feels like he has to put up a wall that's constantly around him and he's filtering everything that comes out of my mouth.

When these subjects were asked how they would describe what it was like for them to be a gay or lesbian educator. They were asked how their personal fear affected them in being open as they established and maintained relationships with others in their school communities.

Robert described it as living two different lives, elaborating about how he feels, "Very schizophrenic--I've had to lead a split life, personal vs. professional. It affects my own sense of accomplishment. It's so exhausting." There were times when he felt like he was being forced back into the closet again. "It's so uncomfortable on a daily basis." He stated that "if straight teachers 
have affairs it's no big deal, but him dating another man is catastrophic. I'm constantly filled with fear."

Robert was the only educator participating in this study who expressed his oppression as a factor in his career. Adam, however, claimed that his sexual orientation did not make him feel differently in a school setting noting, "I suppose it's like being a straight educator. My sexual orientation doesn't define me in a way that I feel any different than anyone else."

George and Edward both felt that there were not an excessive number of challenges and burdens attached to being gay teachers. Edward's challenge seemed more a frustration than a challenge, commenting, "A challenge is that I'm not able to fully connect with some of the students. There are some students who are gay, and I have to draw a line of professionalism about how to confide in them."

Richard had most likely experienced the most threatening challenges and burdens for being an openly gay teacher stating, "It's been a constant struggle with the principal. I've had death threats, harassing phone calls, a brick thrown through the window of my home (with a note-'die fags'), my car tires have been deflated." Rose, also relating to the issue of anxiety, isolation and fear, emphatically commented, "There is anxiety and isolation as a lesbian educator. My partner and I have gone through numerous emotional days. She's tired of me saying I feel bound by not being out, because she is out at her workplace."

Scott, a Catholic school religion teacher, expressed extreme anxiety and fear at the idea of being an openly gay teacher. "I am in an environment where there is some very overt homophobia, in a very major way." After he came out, there was another teacher who teaches recovery therapy, and he challenged him on that and it caused a huge episode and after three years he still claimed that his questioning him defamed his character, threatening to sue me. "So that's the kind of environment I work in." Scott went on to express just how much anxiety he does feel in his Catholic school setting.

Dennis, while not in the same school, agreed noting, "As out as I am, I do feel like there are restrictions on myself and I have to be careful. It does create a lot of stress and anxiety." So yes there is fear, there is anxiety, it is something he thinks about. When asked if he felt he could be fired for being gay, Dennis, the Catholic school counselor and boys' soccer coach, claimed he had a great amount of fear of being fired for being gay. He went on to say that every day when he walks into the building, he thinks about it. "I have had alumni and parents ask for my job. I've been told to keep quiet (about my sexual orientation) by the administration, over various issues."

Educators working in public school settings seemed no less traumatic than those working in Catholic schools. Robert felt there were multiple challenges and burdens associated with being a gay administrator, as he described the anxiety and isolation he felt. "It made me somewhat depressed. I wasn't really happy with the idea that I couldn't be myself. When we had Christmas parties and other events, I could not be who I really was, it was frustrating." But he knew that in itself would be a death sentence for him and his career. 


\section{Relationship Formation and Maintenance}

All of these educators admitted being out to some of their colleagues, and some even to their administration within their school communities. When asked whether they were out to their students, colleagues, administration, and families, their responses varied from individual to individual, with even some variation within the same Catholic school community.

When asked about how out she was to her students/colleagues/parents of your students and family, Rose responded, "I'm out to many of my colleagues but not all." She went on to state that they have had conversations and they are understanding, and are friends of hers, but she was not out to their kids.

The Catholic school educators also expressed varying levels of openness in their school communities. Mayo's (2008) study with seven gay male teachers found that only one participant was out to his entire school community, but all of the participants were out to some of their colleagues. David felt like he's open to everybody. "I've had students who will approach me and ask me where they can go to find some support, so apparently my persona is like an accepting gay person. Whether gay or straight some of the students talk to me."

One participant in Mayo's (2008) study claimed that he has taken a watchful eye approach, as he has noticed the need for some type of a safe zone, a gay friendly area for students struggling with their sexual identities. David did mention that many of the teachers and administrators in his Catholic school did have human rights/equal rights $(=)$ stickers on their doors, but claimed that did not mean that students or staff members could feel safe talking about homosexuality in those rooms.

Although Rose taught in the same school setting as David, she did not feel like she could be as open with everyone. Rose had claimed that everyone just assumed she was heterosexual. While there may be some negative effects of coming out to students, many of the accounts of teachers who have come out, as well as those who have had gay or lesbian teachers, indicate that the effect is positive, as it helps others come out (Jennings, 2005). Scott, a religion teacher in a Catholic school said, "I did come out a few years ago to my faculty. I just assumed that people knew. I'm 39 , and single, people should be able to connect the dots and figure it out. Kids don't ask questions."

Participants in Mayo's (2008) study identified opportunities to form relationships with their colleagues in an attempt to combat feeling isolated. Robert, who was eventually fired for being gay, commented, "Quasi-out with a few select faculty members. It was never really spoken about specifically, but I had a couple that I knew were supportive". He claimed that when his partner died in the spring of 2003, a few of his colleagues offered their condolences and were supportive.

Richard, however, was out to everyone in his school community, despite his administration's disapproval. He stated, "I'm just out to everybody in the community. It's no secret that I'm gay. I'm openly gay. I have a rainbow sticker on my car. I've had one for years." When he first put the sticker on his car, his principal told him to tell the students that he just liked rainbows, if he were asked. 
George, who had a contract which protected him from being fired for being a gay man, noted that he was very comfortable being "openly gay" to everyone in his school community. Even Edward was not threatened by being openly gay, commenting that he doesn't tell everybody, but if they asked he would have no problem being honest with them. Robert, on the other hand, a rural school ex-administrator, never experienced that comfort level that others expressed having with her colleagues. When asked if he ever felt comfortable bringing his partners or boyfriends to school functions or social events, Robert explained, "No, I never brought my partner to any school functions. I never felt comfortable doing that."

While many of these educators were out to some of their colleagues and administration, most were not out to students or school community families. Jackson (2007) found that teachers "viewed disclosing their gayness to students as the real mark of coming out at school" (p. 68). Three educators involved with this study claimed that they and their partners were invited to social events with their colleagues, and were comfortable attending school functions with their partners.

Another question about these educators' relationships focused on how they dealt with anti-gay comments or jokes, in regard to how well their colleagues, administrators, and students respected them as homosexuals. These educators would not hear anti-gay comments or jokes if they were valued as individuals (Mayo, 2008). Relationships determine how we speak and what we talk about with others. A true friend or trusted colleague or administrator will not allow others to speak to you or about you in a pejorative way.

Robert, the ex-administrator, commented, "At first, I did like a lot of people do, I laughed and walked away. I didn't publicly comment when they were made." Later, however, he said he did become defensive, "claiming that I had a gay family member, and I didn't appreciate those comments. When students made comments, I treated them as any other derogatory slur against any child with the intention of putting someone down."

Susan agreed with Robert about how to handle anti-gay comments from students noting, "The same way I deal with any inappropriate comments. They have no place in the classroom." When asked about comments from colleagues, she merely claimed "it hasn't happened."

Richard felt the same way about comments from his colleagues stating, "I don't really hear anything from my colleagues anymore." Regarding student comments, he agreed with many of the other educators. "I tell students that it's inappropriate and try to take advantage of teachable moments when I can. I don't have a problem with letting a kid know that I find that's so gay insulting." Many of the educators consider anti-gay comments or jokes comparable to any other type of harassing comments students might make to one another.

Adam, the gay ex-principal, also turned anti-gay comments into teachable moments and attempted to make anti-gay comments into teachable moments. "I take anti-gay comments from kids toward one another very seriously. And when I take them very seriously, I have to be very careful about how I explained that to children." He explained that some kids may find the comments hurtful and offensive to them. He explained that we are all very different, and you watch the news and you know that there are gay people. "Some men live with men and women live with women. I'm not telling you how to believe, I'm just telling you that the differences exist, and sometimes people 
get their feelings hurt because you say something hurtful." George, who taught first grade, also created teachable moments when he heard anti-gay comments. "Whether it's about the word gay, or a race issue, we take the time to talk about it." Edward agreed regarding the derogatory comments from students, "I correct the student and tell them it's inappropriate. I don't take it personally, because it isn't directed at me. I would handle it just as I handle any inappropriate comment." He did, however mention that when his colleagues make these hurtful comments or jokes, he just considers them ignorant, as they are unaware of the hurtfulness of their comments.

These educators would not hear anti-gay comments and jokes if they received support from their school communities. When the school system stands as a united front in ending anti-gay jokes and comments, then gay and lesbian school community members will feel safe to be open about the sexuality (Goodman, 2005).

However clear it may seem that all of these gay and lesbian educators negotiated their identities differently, they all did so to some extent. There seemed to be a much greater variation on how those identities affected their relationships with their colleagues, administrators, students, and school community families.

\section{Conclusions}

Each of the six educators interviewed and each of the five participants in the focus group negotiated his/her identity differently. There were some differences in the identity negotiation of the rural, suburban, and Catholic school environment educators, as the urban educators seemed more at ease with being out at school. There was, however, no connection between years of experience as an educator and ease of being out at school.

It was, however, apparent that how the educators negotiated their sexual identity did affect their relationships. The teachers who felt more guarded about their sexual identity were less likely to be open to other members of the school community, being open with only a few trusted colleagues. One of the participants, George, expressed the need to be out in school as it allows others to see that "we are not the stereotypes that they have perceived, seen on TV, or heard about. That we are good teachers, and can lead normal lives; they can see reality, that we are not different because we are homosexual." Edward expressed that he's aware that there are those who think he "shouldn't teach because he's gay," but he just attributes that to a lack of knowledge about homosexuality.

Many of these educators expressed anxiety about taking a significant other to school functions for fear of how their presence might be perceived. A participant in Mayo's (2008) study claiming to be open to everyone in his school community, never attended school events with his partner or took his partner to social functions with his colleagues. This participant claimed, "The fact that I don't socialize with the rest of the faculty is probably due mostly to the fact that I wouldn't feel comfortable. I don't trust some of them" (p. 9). When teachers must choose between their teacher identity and sexuality identity, "they hide their sexual identity because anything related to sexuality is deemed inappropriate for children in the school setting" (Keyser, 2015, p. 443).

To be sure, there are lesbian and gay teachers, counselors, and administrators working in the K-12 school systems. This research provided data illuminating how important a safe and supportive school environment for all staff members is in providing a productive school atmosphere, as 
teachers who live in constant fear of being outed as a gay man or lesbian distracts from an educator's responsibilities. Just as DeLeon and Brunner (2009) found that as a form of coping with the fears of being out or being outed, educators choose to assimilate and remain silent, because as Bishop et al. (2010) found the fear of being openly gay or lesbian educators produced fear of job loss and exclusion, even in the most liberal of schools.

Additionally, Goodman (2005) stated gay and lesbian school community members will not feel safe to be out about their sexuality until the school system takes a united front against anti-gay jokes and comments. The educators in this study agreed, but most also agreed that many of their colleagues and administrators would not agree to such a unified effort. While these educators in this study, as well as other educators not in the study, but with whom I have spoken, agreed that being out in their school communities is absurd. The fear that these teachers spoke about when negotiating their identities, is common among gay men and lesbians working in K-12 school systems. Until school districts are safe for all gay and lesbian students and employees, and there are policies in place to protect against harassment and being fired, fear will continue to keep many of the gay and lesbian educators closeted.

\section{References}

Berg, B. L. (2007). Qualitative research methods for the social sciences ( $6^{\text {th }}$ ed.). Boston, MA: Pearson Education. Equality and Human Rights Commission (EHRC). (2009). Beyond tolerance: Making sexual orientation a public matter. Retrieved from http://www.equalityhumanrights.com

Bishop, H. N., Caraway, C., \& Stader, D. L. (2010). A case for legal protection for sexual minority educators. The Clearing House, 83(3), 84-88. doi: 10.1080/00098651003655878

Capper, C. A. (1999). (Homo)sexualities, organizations and administration: Possibilities for in(queer)y. Educational Researcher, 28(5), 4-11.

Davis, B. (2005). The marriage question. In K. Jennings (Ed.), One teacher in 10 (2 ${ }^{\text {nd }}$ ed.; pp. 25-33). Los Angeles, CA: Alyson Publications.

DeLeon, M. J., \& Brunner, C. C. (2009). Lesbian and gay public school administrators. In J. W. Koschoreck \& A. K. Tooms (Eds.), Sexuality matters: Paradigms and policies for educational leaders (pp. 157-177). Lanham, MD: Rowman \& Littlefield Education.

Goodman, J. M. (2005). Homophobia prevention and intervention in elementary schools: A principal's responsibility. Journal of Gay \& Lesbian Issues in Education, 3(1), 111-116.

Gumbleton, T. J. (2001). Teaching authentically. America, 184(14), 19-20.

Jackson, J. M. (2007). Unmasking identities: An exploration of the lives of gay and lesbian teachers. Lanham, MD: Lexington Books.

Jackson, J. M. (2006). Removing the masks: Considerations by gay and lesbian teachers when negotiating the closet door. Journal of Poverty, 10(2), 27-52.

Jennings, K. (Ed.). (2005). One teacher in 10 ( $2^{\text {nd }}$ ed.). Los Angeles, CA: Alyson Books.

Keyser, W. (2015). School's out: Gay and lesbian teachers in the classroom. Anthropology \& Education Quarterly, $46,442-443$.

Lugg, C. A. (2003). Sissies, faggots, lezzies, and dykes: Gender, sexual orientation, and a new politics of education. Educational Administration Quarterly, 39(1), 95-134.

Maher, M. J. (2003). Some background on addressing the topic of homosexuality in Catholic education. Catholic Education: A Journal of Inquiry and Practice, 6(4), 498-515.

Maher, M. J. (2001). Being gay and lesbian in a Catholic high school: Beyond the uniform. New York, NY: Harrington Park Press.

Maher, M. J., \& Sever, L. M. (2007). What educators in Catholic schools might expect when addressing gay and lesbian issues: A study of needs and barriers. Journal of Gay \& Lesbian Issues in Education, 4(3), 79-111.

Mayo, J. B. (2008). Gay teachers' negotiated interactions with their students and (straight) colleagues. The High School Journal, 92(1), 1-10.

Patton, M. Q. (2002). Qualitative research and evaluation methods (3 ${ }^{\text {rd }}$ ed.). Thousand Oaks, CA: Sage. 
Hooker: Hiding or out? Lesbian and gay educators reveal their experiences about their sexual identities in their K-12 schools

Pizer, J. C., Sears, B., Mallory, C., \& Hunter, N. D. (2012, spring). Evidence of persistent and pervasive workplace discrimination against LGBT people: The need for federal legislation prohibiting discriminations and providing equal employment benefits. Loyola of Los Angeles Review, 45, 1715-779.

Wright, T. E. (2010). LGBT educator's perceptions of school climate. Kappan, 91(8), 49-53. 